J. Clin. Chem. Clin. Biochem.

Vol. 28, 1990, pp. 203-210

(C) 1990 Walter de Gruyter \& Co.

Berlin · New York

\title{
Comparison of Five Routine Methods with the Candidate Reference Method for the Determination of Bilirubin in Neonatal Serum
}

\author{
By H. Schlebusch ${ }^{1}, K$. Axer $^{1}, C h . S c h n e i d e r^{1}, N$. Liappis $^{2}$ and G. Röhle ${ }^{3}$ \\ ${ }^{1}$ Universitäts-Frauenklinik (Direktor: Prof. Dr. D. Krebs) Bonn \\ ${ }^{2}$ Universitäts-Kinderklinik (Direktor: Prof. Dr. M. Lentze) Bonn \\ ${ }^{3}$ Institut für Klinische Biochemie (Direktor: Prof. Dr. Dr. F. Bidlingmaier) der Universität Bonn
}

(Received July 26/December 4, 1989)

Summary: Using five routine methods and the candidate reference method of Doumas (Clin. Chem. 31, 17791789 (1985)), total bilirubin was determined in 77 neonatal serum samples (concentration range 63-444 $\mu \mathrm{mol} / 1$, average value $227 \mu \mathrm{mol} / \mathrm{l})$.

Four of the routine methods (Jendrassik \& Grof's (Biochem. Z. 297, $81-89$ (1938)) method, Hertz's (Scand. J. Clin. Lab. Invest. 33, 215-230 (1974)) method, the bilirubinometer procedure, and the method employing 2,5-dichlorophenyldiazonium (Scand. J. Clin. Lab. Invest. 29, Suppl. 126, Abstr. 11. 12. (1972))) gave values that were generally higher than those of the reference method. In contrast, the results from Vink's (Clin. Chem. 34, 67-70 (1988)) direct spectrophotometric method differed only negligibly from those of the reference method. The accuracy of Jendrassik \& Grof's method, and to a limited extent that of the 2,5-dichlorophenyldiazonium method, can be improved by redetermination of the molar absorption coefficient, or by using a standard containing a matrix of human albumin, with an assigned value determined by the reference method. It was found that Hertz's direct spectrophotometric method can be replaced by that of Vink.

The accuracy of the bilirubinometer results could be improved only by using calibrators with assigned values specific for the bilimeter, or by calibration with a serum pool.

\section{Introduction}

Owing to its great diagnostic importance, the bilirubin concentration of neonatal serum must be determined with high precision and accuracy (1).

Collaborative interlaboratory surveys, however, have revealed an unsatisfactorily wide scatter of results for the determination of bilirubin under similar operational conditions, and systematic differences between the results from the various routine methods of determination $(2,3)$. It is not yet known whether and to what extent these differences also occur in the analysis of native neonatal sera, or whether the problem is due to the matrices of the control sera.
In 1985, Doumas et al. (4) described a method for the determination of total bilirubin, which largely meets the requirements of a reference method. This was used as the "reference method" in the present study.

In addition, lyophilized bilirubin samples have recently become available, which contain a matrix of human albumin, and which have assigned values established by weighing the analyte and by determination with the reference method $(5,6)$. According to Vink et al. (5), it may be possible to use this material as a universal calibrator for the determination of bilirubin. 
In the present work, the results from five routine methods and a micro-version of the reference method were compared, and their performance was evaluated by analysis of neonatal samples and standards.

\section{Materials and Methods}

\section{Native samples}

Seventy-seven samples of neonatal venous blood were analysed by 6 different methods. In addition, 12 serum samples were analysed by only the candidate reference method and the 2,5dichlorophenyldiazonium method.

To obtain enough material for analysis, it was sometimes necessary to pool the residues from 2 different sera with similar bilirubin concentrations. Visibly haemolytic samples (i. e. haemoglobin $>1 \mathrm{~g} / \mathrm{l}$ ) were excluded.

Until analysis, serum samples were stored at $-20^{\circ} \mathrm{C}$ in aliquots of $500 \mu \mathrm{l}$; after thawing, they were centrifuged, then analysed within 6 hours.

All operations were conducted without laboratory illumination and in subdued light.

\section{Control sera}

Three control samples were analysed in each series. Two samples were obtained from the Rijksinstituut voor Volksgezondheid en Milieuhygiene, Bilthoven, The Netherlands; these were lyophilized solutions of bilirubin and human albumin $(5,6)$ : P1 (Lot-No. 870624) certified value $308.1 \mu \mathrm{mol} / 1$, and P2 (Lot-No. $870622)$ certified value $106.1 \mu \mathrm{mol} / 1$. The third sample was "Stabil" (manufactured by Baxter, Lot-No. BIC 975), which also contains human albumin.

In order to determine precision in series, and to investigate the agreement between the reference method (4) and our microversion, we analysed both "Sta-bil" and the control serum "Precibil" (manufactured by Boehringer Mannheim, Lot-No. 157908; containing human serum as the matrix).

\section{Photometer}

For methods $1-5$, all measurement were performed in a double beam spectrophotometer (Perkin Elmer 554) with a band width of $1 \mathrm{~nm}$, using quartz cuvettes (Suprasil, manufactured by Hellma, light path $10 \mathrm{~mm}$ ).

The accuracy of the wavelength setting was checked with holmium nitrate solution $\left(\lambda_{\max }=536.7 \mathrm{~nm}\right.$ and $\left.640.0 \mathrm{~nm}\right)$ and the emission line of the deuterium lamp $(\lambda=656.1 \mathrm{~nm})$. Errors of less than $0.5 \mathrm{~nm}$ were found.

Absorption accuracy was monitored with haemiglobin cyanide solutions and gray filters. The assigned values for the gray filters $(\lambda=598 \mathrm{~nm})$ and haemiglobin cyanide solutions $(\lambda=546.1 \mathrm{~nm})$ were determined by the Physikalisch-Technische Bundesanstalt, Berlin.

For direct spectrophotometry without dilution, we used a bilirubinometer ("Bilimeter" from Ortho Diagnostic Systems $\mathrm{GmbH}$ ) with the capillaries recommended by the manufacturer. According to the manufacturer, the bilimeter measures light absorption at $455 \mathrm{~nm}$ and $575 \mathrm{~nm}$. For calibration purposes, we used "Sta-bil" (Lot BIC 975, with a value of $332 \mu \mathrm{mol} / 1$ quoted for use with bilimeters).

\section{Pipetting, dilution and mixing}

In addition to officially calibrated glass pipettes (from Brand, Wertheim), we also used a Microlab-M-Dilutor (manufactured by Hamilton) and a Multipette 4780 (manufactured by Eppendorf-Gerätebau). Precision and accuracy of the apparatus were tested according to the recommendations of the National Committee for Clinical Laboratory Standards USA (NCCLS Vol 4, No. 6). A vortex mixer was used for mixing.

\section{Measurement technique}

All measurements were made against air, and the position of the cuvette in the cuvette holder was unchanged during the entire series. Sample blanks and analytical samples were measured after each other in series. Before each spectrophotometric measurement the cuvette was washed at least once with the solution under test. After each measurement, the contents of the cuvette were sucked out with a pump.

After every ten measurements, the cuvette was filled with reagent solution to test for photometer drift (for details see 1.c. (4)).

\section{Analytical methods}

1. "Reference method" (4)

Reagents

Caffeine solution:

Sodium acetate $\quad 0.68 \mathrm{~mol} / \mathrm{l}$

Sodium benzoate $\quad 0.39 \mathrm{~mol} / \mathrm{l}$

EDTA $\quad 3.0 \mathrm{mmol} / \mathrm{l}$

Caffeine $\quad 0.193 \mathrm{~mol} / 1$

Tartrate solution:

Potassium sodium tartrate $\quad 1.13 \mathrm{~mol} / \mathrm{l}$

$\mathrm{NaOH}$

$1.88 \mathrm{~mol} / 1$

Sulphanilic acid solution:

Sulphanilic acid $\quad 0.029 \mathrm{~mol} / \mathrm{l}$

$\mathrm{HCl}$

$0.47 \mathrm{~mol} / \mathrm{l}$

Sodium nitrite solution:

Sodium nitrite

$0.072 \mathrm{~mol} / 1$

Diazo-reagent:

Sulphanilic acid solution $(10 \mathrm{ml})$ mixed with sodium nitrite solution $(0.25 \mathrm{ml})$

Procedure (micro-version): Serum $(50 \mu \mathrm{l})$ was mixed with caffeine reagent $(400 \mu \mathrm{l})$. After $10 \mathrm{~min}$, diazo-reagent $(100 \mu \mathrm{l})$ was added. The mixture was allowed to stand for $10 \mathrm{~min}$, followed by the addition of tartrate solution $(300 \mu \mathrm{l})$. The mixture was allowed to stand for a further $10 \mathrm{~min}$ before determination of absorption. The sample blank was prepared in the same way as the sample, except that sulphanilic acid solution $(100 \mu \mathrm{l})$ was added instead of diazo-reagent. Measurements were performed at $598 \mathrm{~nm}$ against air (for details see 1.c. (4)).

Calculation: $c(\mu \mathrm{mol} / 1)=\left(\mathrm{A}_{\mathrm{P}}-\mathrm{A}_{\mathrm{L}}\right) \times 225.2$.

In this micro-version all volumes are 10 times less than those used in the original version; the procedures for performance of the assay are unchanged.

\section{Jendrassik \& Grof's method (7)}

Reagents were obtained from Boehringer Mannheim (order No. 123 927). 


\title{
Werner Schwemmler
}

\section{Symbiogenesis}

A Macro-Mechanism of Evolution

\author{
Progress Towards a Unified Theory \\ of Evolution Based on Studies in Cell Biology
}

1989. $17 \mathrm{~cm} \times 24 \mathrm{~cm}$. X, 225 pages. Numerous illustrations.

Softcover. DM 70,-; approx. US \$39.00 ISBN 3110121328

The book describes evolution - from the big bang through elementary particles, atoms, molecules and cells to humans - as a continuing process. Evolution is the result not only of the familiar micro-mechanisms, but also of more profound macro-mechanisms. A model for a unified theory of evolution is developed from consideration of both types of mechanism. This model can be used as the basis for a modern theoretical biology in which the central concept is symbiosis; in a broad sense, associations of non-living systems down to the complex systems of living cells, the endocytobioses. The structures and functions of endocytobioses follow patterns which permit their arrangement in a periodic system of cells. The endocytobiotic cell theory suggests experimental approaches to the analysis of embryonic development, tumor formation and intracellular clocks. The new field of endocytobiology comprises a multidiscipline approach to these experiments.

\section{Table of Contents}

\section{Evolution Research}

The epistemological problem - The methodological problems $\cdot$ References

\section{Cosmogenesis}

Phenomenon · Hypotheses · Data (Redshift, Background radiation. Critical density. Particle interaction) - Reconstruction (The problem. Pulsation model) $\cdot$ Micromechanisms of cosmogenesis $\cdot$ References

\section{Chemogenesis}

Phenomenon · Hypotheses · Data (Geogenesis. Boundary condition. Simulation experiment) $\cdot$ Reconstruction (The problem. Self-organization model) . Micro-mechanisms of chemogenesis - References

Biogenesis: Precyte

Phenomenon - Hypotheses · Data (Fossil discovery. Cell component simulation. Evolution experiment in vitro. Computer test) - Reconstruction (The problem. Hypercycle model) $\cdot$ Summary $\cdot$ References

\section{Biogenesis: Procyte}

Phenomenon - Hypotheses - Data (Biotope study. Fossil discovery. Metabolic homology. Sequence analysis). Reconstruction (The problem. Archaebacterium model) Summary $\cdot$ References

\section{Biogenesis: Eucyte}

Phenomenon - Hypotheses - Data (Cell fossil discovery. Organelle autonomy. Endocytobiont analogy. Procyte homology) · Reconstruction (The problem. Endocytobiont model) - Summary - Micro-mechanisms of biogenesis $\cdot$ References

\section{Sociogenesis}

Phenomenon - Hypotheses · Data (Embryonic development. Phylogenesis. Brain evolution. Evolution of speech) $\cdot$ Reconstruction (The problem. Fulguration model) - Future development of mankind - Micromechanisms of cultural evolution $\cdot$ References

\section{Macro-mechanisms of Evolution}

Phase principle $\cdot$ Modular principle $\cdot$ Periodicity principle (Preliminary periodic system of cells. Possible periodicity in cultural genesis) - Consequences for biogenesis $\cdot$ Summary $\cdot$ References

\section{Experimental application}

Endocytobiosis as an intracellular ecosystem - Endocytobiosis of leafhoppers (Oogenesis. Embryogenesis. Gene expression. Physiochemistry. Model system) • Endocytobiology as an interdisciplinary research field . References

\section{Appendix}

Author index $\cdot$ Subject index 


\section{Reagents}

Caffeine solution:

$\begin{array}{ll}\text { Sodium benzoate } & 0.52 \mathrm{~mol} / 1 \\ \text { Caffeine } & 0.26 \mathrm{~mol} / 1\end{array}$

Tartrate solution:

Potassium sodium tartrate $\quad 0.93 \mathrm{~mol} / \mathrm{l}$

$\mathrm{NaOH}$

$1.9 \mathrm{~mol} / \mathrm{l}$

Sulphanilic acid solution:

Sulphanilic acid

$\mathrm{HCl}$

$0.029 \mathrm{~mol} / \mathrm{l}$

$0.17 \mathrm{~mol} / 1$

Sodium nitrite solution:

Sodium nitrite

$0.025 \mathrm{~mol} / \mathrm{l}$

Procedure: Sulphanilic acid solution $(100 \mu \mathrm{l})$ and sodium nitrite solution $(20 \mu \mathrm{l})$ (replaced by $20 \mu \mathrm{l}$ distilled water in the sample blank) were pipetted into an Eppendorf reaction vessel, then mixed with caffeine solution $(400 \mu \mathrm{l})$ and serum $(50 \mu \mathrm{l})$. After $15 \mathrm{~min}$, tartrate solution $(400 \mu \mathrm{l})$ was added and mixed, and the absorption was measured at $578 \mathrm{~nm}$ after $15 \mathrm{~min}$.

Calculation: $\left.c(\mu \mathrm{mol} / \mathrm{l})=\mathrm{A}_{\mathrm{P}}-\mathrm{A}_{\mathrm{L}}\right) \times 293$.

\section{2,5-Dichlorophenyldiazonium (DPD) method (8)}

Reagents were obtained from Boehringer Mannheim (order No. 124943).

Reagents

Diazo-reagent:

$\begin{array}{ll}\text { 2,5-Dichlorophenyldiazonium chloride } & 1 \mathrm{mmol} / 1 \\ \mathrm{HCl} & 0.1 \mathrm{~mol} / 1 \\ \text { Detergent } & \end{array}$

Blank value reagent:

$\mathrm{HCl}$

$0.1 \mathrm{~mol} / 1$

Detergent

Procedure: Serum $(20 \mu \mathrm{l})$ was mixed with diazo-reagent $(1000$ $\mu l)$ in an Eppendorf reaction vessel, and absorbance measured at $546 \mathrm{~nm}$ after $15 \mathrm{~min}$. For the sample blank, diazo-reagent was replaced by blank value reagent $(1000 \mu \mathrm{l})$.

Calculation: $c(\mu \mathrm{mol} / \mathrm{l})=\left(\mathrm{A}_{\mathrm{P}}-\mathrm{A}_{\mathrm{L}}\right) \times 1112$.

\section{Direct spectrophotometry according to Hertz et al. (9)}

Procedure: Serum $(50 \mu \mathrm{l})$ was diluted with $1000 \mu \mathrm{l}$ of potassium tetraborate buffer $(100 \mathrm{mmol} / \mathrm{l}, \mathrm{pH} 9.3)$, and absorption was measured immediately at $466 \mathrm{~nm}$ and $522 \mathrm{~nm}$.

Calculation: $c(\mu \mathrm{mol} / \mathrm{l})=21 \times\left(21.6 \times \mathrm{A}_{466}-27.4 \times \mathrm{A}_{522}\right)$.
5. Direct spectrophotometry according to Vink (10)

Caffeine solution:

Sodium acetate $\quad 1.52 \mathrm{~mol} / \mathrm{l}$

Sodium benzoate $\quad 0.52 \mathrm{~mol} / 1$

EDTA $3 \mathrm{mmol} / 1$

Caffeine $\quad 0.257 \mathrm{~mol} / \mathrm{l}$

Procedure: Serum $(50 \mu \mathrm{l})$ was diluted with caffeine reagent $(1000 \mu \mathrm{l})$. Absorption of the mixture was measured within 15 $\min$ at $465 \mathrm{~nm}$ and $528 \mathrm{~nm}$.

Calculation: $c(\mu \mathrm{mol} / \mathrm{l})=21 \times 21.6\left(\mathrm{~A}_{465}-\mathrm{A}_{528}\right)$.

\section{Direct spectrophotometry without dilution (11)}

Serum samples were added to capillary cuvettes and absorption was measured in the bilimeter according to the procedure of the manufacturer. The zero of the instrument was adjusted before each measurement. The instrument was calibrated with "Sta-bil" Lot 975, using the assigned value of the manufacturer. Results are given directly in $\mu \mathrm{mol} / 1$ in a digital read-out.

Transformation of the analytical results with the aid of a standard

The analytical results $\left(\mathrm{A}_{\mathrm{i}}\right)$ were multiplied by the quotient derived by dividing the assigned value of $\mathrm{P} 1(308.1 \mu \mathrm{mol} / \mathrm{l})$ by the analytical result of the control sample $\mathrm{P} 1$ in the respective series $\left(A_{P 1}\right)$

$$
A_{t}=A_{i} \times \frac{308.1}{A_{P 1}}(\mu \mathrm{mol} / 1) .
$$

\section{Statistics}

For the comparison of methods the regression line was calculated by the method of Passing \& Bablok (12).

\section{Results and Discussion}

\section{Precision in series}

Data for precision in series $(\mathrm{N}=20)$ are shown in table 1 for the control samples "Sta-bil" and "Precibil". The greatest imprecision was shown by the DPD method with a variation coefficient of $1.1 \%$, whereas the other procedures showed markedly smaller scatters. For this reason, duplicate values were not considered necessary for the method comparison.

Tab. 1. Analytical results and precision in series $(N=20)$ for the control sera "Sta-bil" and "Precibil" determined by 7 different methods $(\overline{\mathrm{x}}=$ average value, $\mathrm{CV}=$ coefficient of variation).

\begin{tabular}{|c|c|c|c|c|c|}
\hline \multirow[t]{2}{*}{ No. } & \multirow[t]{2}{*}{ Method } & \multicolumn{2}{|l|}{ Sta-bil } & \multicolumn{2}{|l|}{ Precibil } \\
\hline & & $\begin{array}{l}\overline{\mathrm{x}} \\
(\mu \mathrm{mol} / \mathrm{l})\end{array}$ & $\begin{array}{l}\mathrm{CV} \\
(\%)\end{array}$ & $\begin{array}{l}\overline{\mathrm{x}} \\
(\mu \mathrm{mol} / \mathrm{l})\end{array}$ & $\begin{array}{l}\mathrm{CV} \\
(\%)\end{array}$ \\
\hline $1 \mathrm{a}$ & Doumas (original version) & 318.7 & 0.5 & 269.6 & 0.5 \\
\hline $1 \mathrm{~b}$ & Doumas (micro version) & 319.5 & 0.3 & 270.1 & 0.5 \\
\hline 2 & Jendrassik \& Grof & 314.1 & 0.4 & 277.1 & 0.3 \\
\hline 3 & DPD & 324.1 & 1.1 & 292.4 & 1.1 \\
\hline 4 & Hertz & 329.6 & 0.8 & - & - \\
\hline 5 & Vink & 320.4 & 0.3 & - & - \\
\hline 6 & Bilimeter & 332.9 & 1.2 & 313.8 & 0.5 \\
\hline
\end{tabular}


Comparison of results from the candidate reference method of Doumas (4) with those from our microversion of the method showed no significant differences between the scatter of values and the average values of the two control samples (which contain human albumin or human serum as the matrix). In the subsequent work, therefore, only the micro-version was used.

Precision from day to day and accuracy in control samples

Results for control samples P1, P2 and "Sta-bil" are shown in table 2. Two of the routine methods are based on the measurement of a coloured azo-pigment, and the scatter of values for these methods was markedly higher than for Doumas' and the other methods, which use direct spectrophotometry. Satisfactory agreement with the certified value of P1 was achieved only by methods 1 and 5 (methods of Doumas and Vink), with deviations of $0.32 \%$ and $0.75 \%$, respectively. Variations in this value were also found by Vink et al. (10). In the analysis of P2, these same two methods gave values that differed from the certified value by $-1.1 \%$ and $0.75 \%$, respectively. Method 2 also produced values for $\mathrm{P} 2$ that differed only slightly $(1.4 \%)$ from the certified value.
Recorded values for the control sample "Sta-bil" also depended markedly on the method of determination. The results of these analyses, however, also appeared to be influenced by the matrix of the control material. This becomes very apparent if the results are calculated using sample $\mathrm{P} 1$ (which has the same matrix as P2) as the standard (tab. 3). The values for P2 from the various methods then show smaller differences. The bilimeter results were an exception, still showing an appreciable deviation from the other analyses, but this can be attributed to the non-linearity of the instrument response in this analytical range (13). On the other hand, in the analysis of "Sta-bil", the differences were amplified when the calculation was based on standardization with P1.

Standardization with P1 also improved the precision from day to day for the analysis of $\mathrm{P} 2$. For the analysis of "Sta-bil", however, some methods even showed a greater scatter when the calculation was based on standardization with P1.

\section{Comparison of methods}

The results of the method comparison are shown in fig. $1 \mathrm{a}-1 \mathrm{e}$ as "residual plots". Since the linear measurement region of the bilirubinometer does not extend

Tab. 2. Analytical results and precision from day to day $(\mathrm{N}=18)$ for control sera $\mathrm{P} 1$ (assigned value $308.1 \mu \mathrm{mol} / \mathrm{l}), \mathrm{P} 2(\mathrm{assigned}$ value $106.1 \mu \mathrm{mol} / \mathrm{l}$ ) and "Sta-bil" (assigned values: Jendrassik \& Grof $318 \mu \mathrm{mol} / 1, \mathrm{DPD} 313 \mu \mathrm{mol} / 1$, bilimeter $332 \mu \mathrm{mol} / \mathrm{l}$ ) determined by 6 different methods $(\overline{\mathrm{x}}=$ average value, $\mathrm{CV}=$ coefficient of variation).

\begin{tabular}{|c|c|c|c|c|c|c|c|}
\hline \multirow[t]{2}{*}{ No. } & \multirow[t]{2}{*}{ Method } & \multicolumn{2}{|l|}{ P1 } & \multicolumn{2}{|l|}{$\mathrm{P} 2$} & \multicolumn{2}{|l|}{ Sta-bil } \\
\hline & & $\begin{array}{l}\overline{\mathrm{x}} \\
(\mu \mathrm{mol} / \mathrm{l})\end{array}$ & $\begin{array}{l}\mathrm{CV} \\
(\%)\end{array}$ & $\begin{array}{l}\overline{\mathrm{x}} \\
(\mu \mathrm{mol} / \mathrm{l})\end{array}$ & $\begin{array}{l}C V \\
(\%)\end{array}$ & $\begin{array}{l}\overline{\bar{x}} \\
(\mu \mathrm{mol} / \mathrm{l})\end{array}$ & $\begin{array}{l}\text { CV } \\
(\%)\end{array}$ \\
\hline $1 \mathrm{~b}$ & Doumas (micro version) & 307.1 & 1.1 & 104.9 & 1.3 & 316.4 & 1.3 \\
\hline 2 & Jendrassik \& Grof & 317.3 & 1.7 & 108.0 & 3.5 & 312.6 & 2.1 \\
\hline 3 & DPD & 329.8 & 2.5 & 114.2 & 2.4 & 322.9 & 2.5 \\
\hline 4 & Hertz & 303.2 & 1.0 & 102.3 & 2.0 & 334.1 & 1.1 \\
\hline 5 & Vink & 305.8 & 1.1 & 105.3 & 1.3 & 317.6 & 0.8 \\
\hline 6 & Bilimeter & 298.9 & 1.1 & 114.3 & 2.0 & 332.6 & 1.2 \\
\hline
\end{tabular}

Tab. 3. Analytical results and precision from day to day $(\mathrm{N}=18)$ for control sera $\mathrm{P} 2$ and "Sta-bil". The results were calculated using control serum P1 (certified value $308.1 \mu \mathrm{mol} / 1$ ) as the standard.

\begin{tabular}{|c|c|c|c|c|c|}
\hline \multirow[t]{2}{*}{ No. } & \multirow[t]{2}{*}{ Method } & \multicolumn{2}{|l|}{$\mathrm{P} 2$} & \multicolumn{2}{|l|}{$\underline{\text { Sta-bil }}$} \\
\hline & & $\begin{array}{l}\overline{\mathrm{x}} \\
(\mu \mathrm{mol} / \mathrm{l})\end{array}$ & $\begin{array}{l}\text { CV } \\
(\%)\end{array}$ & $\begin{array}{l}\overline{\mathrm{x}} \\
(\mu \mathrm{mol} / \mathrm{l})\end{array}$ & $\begin{array}{l}\mathrm{CV} \\
(\%)\end{array}$ \\
\hline $1 b$ & Doumas (micro version) & 105.3 & 1.1 & 317.4 & 1.8 \\
\hline 2 & Jendrassik \& Grof & 104.9 & 1.5 & 303.6 & 2.6 \\
\hline 3 & DPD & 106.7 & 2.0 & 302.3 & 1.8 \\
\hline 4 & Hertz & 104.0 & 1.7 & 339.5 & 1.0 \\
\hline 5 & Vink & 106.1 & 1.5 & 320.0 & 1.4 \\
\hline 6 & Bilimeter & 117.8 & 2.0 & 342.8 & 2.0 \\
\hline
\end{tabular}



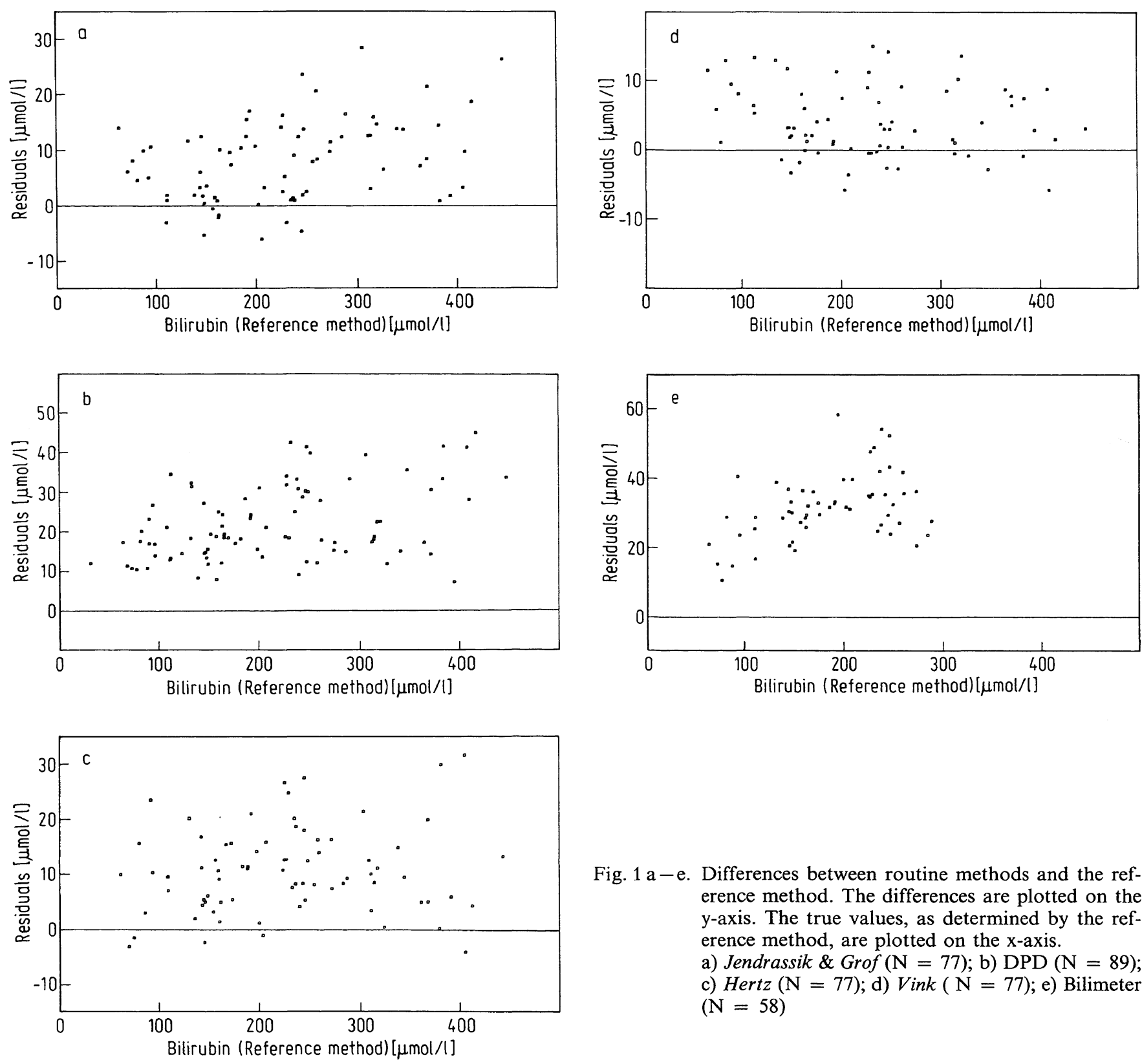

Fig. $1 \mathrm{a}-\mathrm{e}$. Differences between routine methods and the reference method. The differences are plotted on the $y$-axis. The true values, as determined by the reference method, are plotted on the $\mathrm{x}$-axis.

a) Jendrassik \& $\operatorname{Grof}(\mathrm{N}=77)$; b) DPD $(\mathrm{N}=89)$; c) $\operatorname{Hertz}(\mathrm{N}=77)$; d) $\operatorname{Vink}(\mathrm{N}=77)$; e) Bilimeter $(\mathrm{N}=58)$

beyond $300 \mu \mathrm{mol} / 1$ (13), sera with higher concentrations were omitted from the method comparison. Statistical data of the regression analysis are summarized in table 4.

All the routine methods gave values that were generally higher than those from the reference method. The smallest differences were found for Vink's direct spectrophotometric method (fig. 1d), while the results from the bilirubinometer showed the greatest differences (fig. 1e). These two methods also showed respectively the best $(r=0.999)$ and the worst $(\mathrm{r}=0.991)$ correlation with the reference method.

There are several reasons for the differences between the results from the candidate reference method and the routine method of Jendrassik \& Grof, which is

based on the same principle. As early as 1973, Doumas et al. (14) showed that differences between routine methods can be explained to a large extent by faulty calibration. This is certainly also true in the present case. In the candidate reference method a molar absorption coefficient of $7550 \mathrm{~m}^{2} / \mathrm{mol}\left(755001 \cdot \mathrm{mol}^{-1}\right.$ $\cdot \mathrm{cm}^{-1}$ ) (at $598 \mathrm{~nm}$ ) is used, whereas the molar absorption coefficient for the routine method is 6620 $\mathrm{m}^{2} / \mathrm{mol}\left(66200 \mathrm{l} \cdot \mathrm{mol}^{-1} \cdot \mathrm{cm}^{-1}\right)$ (at $\left.578 \mathrm{~nm}\right)$, which corresponds to $6940 \mathrm{~m}^{2} / \mathrm{mol}\left(694001 \cdot \mathrm{mol}^{-1} \cdot \mathrm{cm}^{-1}\right)$ at $598 \mathrm{~nm}$.

These differences between the molar absorption coefficients would give rise to a difference of $8 \%$ between the analytical values; in the present comparison, however, the difference was only $3.9 \%$ (at $200 \mu \mathrm{mol} / \mathrm{l}$ ). It therefore appears that albumin-bound bilirubin is not 
Tab. 4. Statistical evaluation of the comparison of 5 routine methods with the reference method $(\mathrm{N}=$ number of samples, $\mathrm{a}=$ intersection of the axis, $\mathrm{b}=$ slope of the regression line, $\mathrm{r}=$ correlation coefficient).

\begin{tabular}{lllccc}
\hline No. & Method & $\mathrm{N}$ & $\mathrm{a}$ & $\mathrm{b}$ & $\mathrm{r}$ \\
\hline 2 & Jendrassik \& Grof & 77 & 1.66 & $1.031^{* *}$ & 0.997 \\
3 & DPD & 89 & $12.57^{*}$ & $1.041^{* *}$ & 0.997 \\
4 & Hertz & 77 & $6.81^{*}$ & 1.015 & 0.997 \\
5 & Vink & 77 & $5.05^{*}$ & 0.992 & 0.999 \\
6 & Bilimeter & 58 & $17.31^{*}$ & $1.076^{* *}$ & 0.991 \\
\hline
\end{tabular}

* The hypothesis $a=0$ is rejected $(\mathrm{p}<0.05)$

** The hypothesis $b=1$ is rejected $(p<0.05)$

completely converted into azobilirubin in the routine method. This is mainly due to the molar ratio of sulphanilic acid to sodium nitrite, which is $16: 1$ in Doumas' method and 6:1 in the routine method. The large excess of sulphanilic acid is needed, however, to ensure the maximal rate of the coupling reaction (15). On the other hand, if a ratio of $3: 1$ is used, the analytical values are about $4 \%$ lower (16).

The absence of EDTA could also be responsible for the differences to Doumas' method. Holtz \& van Dreumel (17) reported that copper interfered with the production of the azo-pigment, by contributing to the formation of an azo-bilirubin-copper complex. This can be prevented by addition of EDTA to the reaction mixture (17).

According to our present findings, the accuracy of Jendrassik \& Grof's method can be improved by standardization with sample P1, or by the use of a redeterminated molar absorption coefficient $\left(6878 \mathrm{~m}^{2} /\right.$ $\mathrm{mol}=68780 \mathrm{l} \cdot \mathrm{mol}^{-1} \cdot \mathrm{cm}^{-1}$ at $578 \mathrm{~nm}$ ).

The results from the 2,5-dichlorophenyldiazonium method (DPD method) are especially surprising. The regression analysis suggests the existence of errors arising from the calibration (the slope of the regression line is 1.041 , which is significantly different from 1 ), and from the blank value (the intersection of the axis lies at $12.57 \mu \mathrm{mol} / 1$, which is significantly different from zero).

The reasons for this are purely speculative, since the method is published only in abstract form, and there is no information on its specificity. The only reported interference is that by indican $(18,19)$. Data for the concentration of indican in neonatal sera are not available, but increased concentrations have been described in pregnancy (20), and it is conceivable that indican is able to cross the placenta. Redetermination of the molar absorption coefficient (4773 vs. $4585 \mathrm{~m}^{2}$ / mol corresponding to 47730 instead of $458501 \cdot \mathrm{mol}^{-1}$ . $\mathrm{cm}^{-1}$ ) did indeed improve the accuracy of the DPD method, but there still remains the problem of an "unspecific" contribution averaging $12.6 \mu \mathrm{mol} / \mathrm{l}$.
When the calibration was performed with $\mathrm{P} 1$, the deviation from the reference values was much less in the range of interest for neonatal determinations (300 $\mu \mathrm{mol} / \mathrm{l}: 1.1 \%, 200 \mu \mathrm{mol} / 1: 3.1 \%, 100 \mu \mathrm{mol} / 1: 9 \%$ ); in the lower measurement range, however, calibration with P1 did not lead to satisfactory accuracy.

The method of Hertz, Dybkaer \& Lauritzen, which is accorded the status of a "reference method" by many authors was regarded to be suitable not only for the determination of bilirubin in neonatal serum, but also in adult serum containing both unconjugated and conjugated bilirubin. The authors based their calculation formula on the analysis of 170 samples, which included only 31 neonatal sera (9); the procedure of Jendrassik \& Grof was used as the "reference method." In the present comparison, however, Hertz's method gave results that were not only significantly different from those of the reference method, but also from those of Jendrassik \& Grof's method. The regression equation ( $\mathrm{y}=$ Hertz's method, $\mathrm{x}=$ Jendrassik \& Grof's method) was y $=0.969 \mathrm{x}+9.25(\mathrm{~b} \neq 1, \mathrm{a} \neq 0$, $\mathrm{p}<0.05)$.

Values from Hertz's method differed from those of the reference method by $10.8 \%$ at $100 \mu \mathrm{mol} / 1$ and $3.8 \%$ at $300 \mu \mathrm{mol} / 1$. Similar differences were reported by Vink (10) and by Blijenberg (21). Since the protein matrix influences the results of Hertz's method $(5,21$, 22), the differences between Hertz's method and the reference method were even greater when P1 was used for calibration (tab. 5).

The best level of agreement with the reference method was shown by Vink's method (10), and this was not altered by calibration with P1. Similarly satisfactory results were reported by Vink (10) and by Hajzer (23).

The greatest deviation from the reference method values was shown by the bilimeter results. In addition to a slope of 1.076 (significantly different from unity), the regression equation showed an intersection of the axis at $17.3 \mu \mathrm{mol} / 1$, which was significantly different from zero. This constant error can be explained by 
Tab. 5. Statistical evaluation of the comparison of methods, using control serum P1 as the standard for calculation of the results.

\begin{tabular}{lllccc}
\hline No. & Method & N & a & b & r \\
\hline 2 & Jendrassik \& Grof & 77 & 1.66 & 1.001 & 0.997 \\
3 & DPD & 89 & $11.77^{*}$ & $0.972^{* *}$ & 0.997 \\
4 & Hertz & 77 & $6.95^{*}$ & $1.031^{* *}$ & 0.997 \\
5 & Vink & 77 & $4.57^{*}$ & 1.001 & 0.999 \\
6 & Bilimeter & 58 & $17.84^{*}$ & $1.109^{* *}$ & 0.991 \\
\hline
\end{tabular}

* The hypothesis $\mathrm{a}=0$ is rejected $(\mathrm{p}<0.05)$

** The hypothesis $b=1$ is rejected $(p<0.05)$

the non-linear calibration curve of the apparatus (13). When the calibration was performed with P1 instead of "Sta-bil", this difference became even greater. As in Hertz's method, an effect of the matrix on the results is also probably responsible for this difference. At the moment, an improvement of accuracy only appears possible by using a serum pool for the calibration. Since the calibration line is non-linear, a twopoint calibration will give approximately correct results even when only in a limited measurement range (13).

\section{Conclusion}

The present study shows "that differences between routine methods and the reference method observed in interlaboratory collaborative studies $(2,3)$ are also observed in the analysis of neonatal serum samples.

\section{References}

1. Gemeinsame Empfehlung der Deutschen Gesellschaft für Gynäkologie und Geburtshilfe, der Deutschen Gesellschaft für Kinderheilkunde und der Berufsverbände zur Frage der Phototherapie bei der Neugeborenen-Hyperbilirubinämie. Gynäkologie und Geburtshilfe (1983), 3/83, 24-25.

2. Blijenberg, B. G., Brouwer, H. J. Roetering, H. A. \& Leijnse, B. (1984) Surveys of neonatal bilirubin - an evaluation. J. Clin. Chem. Clin. Biochem. 22, 609-612.

3. Röhle, G., Schlebusch, H., Geilenkeuser, W. J. \& Kruse, R. (1988) External quality control in the determination of neonatal bilirubin - an approach to the improvement of results. J. Clin. Chem. Clin. Biochem. 26, 441-446.

4. Doumas, B. T., Kwok-Cheung, P. P., Perry, B. W., Jendrzejczak, B., Mc Comb, R. B., Schaffer, R. \& Hause, L. L. (1985) Candidate reference method for determination of total bilirubin in serum: Development and Validation. Clin. Chem. 31, 1779-1789.

5. Vink, K. L. J., van Dreumel, R. J., Schuurman, W., Wikkeling, R. H., van Gansewinkel, R., Phielix, C. J. \& Koedam, J. C. (1987) A candidate standard for use in calibration of total bilirubin in serum. Clin. Chem. 33, 18171821.

6. Wikkeling, R. H., van Dreumel, R. J., Phielix, C. J. \& Koedam, J. C. (1988) Primary bilirubin standards. Fresenius Z. Anal. Chem. 330, 425-426.
For both chemical methods (Jendrassik \& Grof's and the DPD method), the magnitude of this difference is practically the same for control sera and patient sera.

The accuracy of Jendrassik \& Grof's method, and to a limited extent that of the DPD method, can be improved by recalculation of the molar absorption coefficient, or by using P1 for calibration. P1 ("candidate standard for use in calibration of total bilirubin in serum") is, however, unsuitable for calibration of Hertz's direct spectrophotometric method or the bilimeter, because the inaccuracy of both is increased by the matrix of human albumin. This problem can be circumvented by replacing Hertz's method with Vink's method, which shows excellent agreement with the reference method. The bilimeter results can only be improved by calibrating the apparatus with a serum pool, whose analytical value has been established by the reference method (13).

7. Jendrassik, L. \& Grof, P. (1938) Vereinfachte photometrische Methode zur Bestimmung des Blutbilirubins. Biochem. Z. 297, 81-89.

8. Wahlefeld, A. W., Herz, G. \& Bernt, E. (1972) Modification of the Malloy-Evelyn method for a simple determination of total bilirubin in serum. Scand. J. Clin. Lab. Invest. 29, Suppl. 126, Abstract 11.12.

9. Hertz, H., Dybkaer, R. \& Lauritzen, M. (1974) Direct spectrometric determination of the concentration of bilirubins in serum. Scand. J. Clin. Lab. Invest. 33, 215-230.

10. Vink, K. L. J., Schuurman, W. \& van Gansewinkel, R (1988) Direct spectrophotometry of bilirubin in serum of the newborn, with use of caffeine reagent. Clin. Chem. 34, $67-70$.

11. Kupke, I. R. (1977) Die photometrische Mikrobestimmung von Bilirubin im unverdünnten Kapillarplasma von Neugeborenen. Z. Geburtsh. u. Perinat. 181, 456-459.

12. Passing, H. \& Bablok, W. (1983) A new biometrical procedure for testing the equality of measurements from two different analytical methods. J. Clin. Chem. Clin. Biochem. $21,709-720$.

13. Schlebusch, H., Liappis, N., Röhle, G. \& Schneider, Ch. (1989) Zur Kalibration von Bilirubinometern. Lab. Med. $13,364-368$. 
14. Doumas, B. T., Perry, B. W., Sasse, E. A. \& Straumfjord, J. V. (1973) Standardization in bilirubin assays: Evaluation of selected methods and stability of bilirubin sources. Clin. Chem. 19, 984-993.

15. Landis, J. B. \& Pardue, H. L. (1978) Kinetics of the reactions of unconjugated and conjugated bilirubins with pdiazobenzenesulfonic acid. Clin. Chem. 24, 1690-1699.

16. Lo, D. H. \& Wu, T. W. (1983) Assessment of the fundamental accuracy of the Jendrassik-Grof total and direct bilirubin assays. Clin. Chem. 29, 31-36.

17. Holtz, A. H. \& van Dreumel, H. J. (1968) Stabilization of azobilirubin solution by EDTA. Clin. Chim. Acta 20, 355357.

18. Ertingshausen, G., Fabiny Byrd, D. L., Tiffany, T. O. \& Casey, S. J. (1973) Single-reagent method for rapid determination of total bilirubin with the "Centrifichem" analyzer. Clin. Chem. 19, 1366-1369.
19. Poow, R. \& Hinberg, I. H. (1985) Indican interference with six commercial procedures for measuring total bilirubin. Clin. Chem. 31, 92-94.

20. Henning, N. (1966) Klinische Laboratoriumsdiagnostik. 3. Auflage, Urban u. Schwarzenberg, München, pp. 138139.

21. Blijenberg, B. G., Roetering, H. A. \& Leijnse, B. (1987) Reflections on the standardization of total bilirubin in neonatal serum. J. Clin. Chem. Clin. Biochem. 25, $177-$ 181.

22. Vink, K. L. J., Schuurman, W. \& van Gansewinkel, R. (1986) Use of the caffeine reagent in direct spectrophotometry of bilirubin. Clin. Chem. 32, 1389-1393.

23. Hajzer, S. (1989) Comparison of direct spectrophotometric determinations of bilirubin with candidate reference method in sera of newborns. J. Clin. Chem. Clin. Biochem. $27,445-449$.

Dr. H. Schlebusch

Klin.-chem. Laboratorium

der Universitäts-Frauenklinik

D-5300 Bonn-Venusberg 